$\stackrel{N / 2}{N}$

Global Journals Inc

s.

GLOBAL JOURNAL OF MANAGEMENT AND BUSINESS RESEARCH: A

ADMINISTRATION AND MANAGEMENT

Volume 19 Issue 3 Version 1.0 Year 2019

Type: Double Blind Peer Reviewed International Research Journal

Publisher: Global Journals

Online ISSN: 2249-4588 \& Print ISSN: 0975-5853

\title{
Assessment of Social Responsibility in a Public Hospital in the City of Chihuahua through the Boston College Method
}

\author{
By Pedro Javier Martínez Ramos, Myrna Isela García Bencomo, \\ José Gerardo Reyes López \& Hilda Cecilia Escobedo Cisneros
}

Abstract- This paper addresses the assessment of corporate social responsibility in a public hospital through the Boston College method. The stated hypothesis was that, according to the procedure mentioned, where this measuring instrument was applied the public hospital is up to commitment level in at least three of its dimensions.

It was a qualitative, non-experimental transactional field research with bibliographic support. The sample selection was eight people of the following departments: Administrative Director, Head Nurse, Head of Emergency Department, Head of Gynecology and Obstetrics, Accountant, General Cashier, Head of Maintenance, Director's Secretary. On the second part, four patients, two suppliers and five neighbors of the hospital were interviewed. It was carried out in the city of Chihuahua, Chihuahua from September through December 2017.

In regards to the general hypothesis, rejected since only two indicators were found up to commitment, structure, and social affairs management levels.

Keywords: ethics, social responsibility, commitment, philanthropy, boston college method.

GJMBR-A Classification: JEL Code: M14

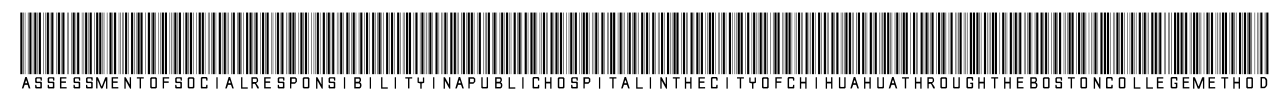

Strictly as per the compliance and regulations of:

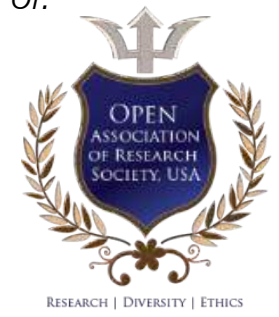

(C) 2019. Pedro Javier Martínez Ramos, Myrna Isela García Bencomo, José Gerardo Reyes López \& Hilda Cecilia Escobedo Cisneros. This is a research/review paper, distributed under the terms of the Creative Commons Attribution-Noncommercial 3.0 Unported License http://creativecommons.org/licenses/by-nc/3.0/), permitting all non-commercial use, distribution, and reproduction in any medium, provided the original work is properly cited. 


\title{
Assessment of Social Responsibility in a Public Hospital in the City of Chihuahua through the Boston College Method
}

\author{
Pedro Javier Martínez Ramos ${ }^{\alpha}$, Myrna Isela García Bencomo ${ }^{\circ}$, José Gerardo Reyes López ${ }^{\circ}$ \\ $\&$ Hilda Cecilia Escobedo Cisneros ${ }^{\omega}$
}

\begin{abstract}
This paper addresses the assessment of corporate social responsibility in a public hospital through the Boston College method. The stated hypothesis was that, according to the procedure mentioned, where this measuring instrument was applied the public hospital is up to commitment level in at least three of its dimensions.

It was a qualitative, non-experimental transactional field research with bibliographic support. The sample selection was eight people of the following departments: Administrative Director, Head Nurse, Head of Emergency Department, Head of Gynecology and Obstetrics, Accountant, General Cashier, Head of Maintenance, Director's Secretary. On the second part, four patients, two suppliers and five neighbors of the hospital were interviewed. It was carried out in the city of Chihuahua, Chihuahua from September through December 2017.
\end{abstract}

In regards to the general hypothesis, rejected since only two indicators were found up to commitment, structure, and social affairs management levels. The most significant results of the interviews were produced in the second part of the research; it was lack of attention to the patient's family, the neighbors and suppliers. Therefore the perception of stakeholder son the hospitals CSR is not very good.

Keywords: ethics, social responsibility, commitment, philanthropy, boston college method.

\section{INTRODUCTION}

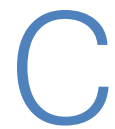
orporate social responsibility arose in the year 1920 with the idea that, if companies in the development of their activities, create wealth or not, consume the natural resources available to humanity, they should pay them back, they should be responsible for their actions, going beyond the generation of economic benefit for the shareholder and creation of employment sources for society, they must also ensure the impact they may cause to the environment; Under this perspective, corporate social responsibility is not a philosophical discourse, rather it is a legal and social requirement.(Sangronis, Gonzalez G., \& Otto, 2014)

The green book on social responsibility says:

Companies understand this concept (of social responsibility) as the voluntary integration, by the companies, of the social and environmental concerns in their commercial operations and their relations with their stakeholders. Being socially responsible does not only mean fully fulfilling legal obligations but also going beyond compliance by investing "more" in human capital, the environment and relations with the stakeholders. (Commission of the European Communities, 2001).

Events such as the Stockholm Conference in 1972, the Brundtland Report in 1987 or the Kyoto Protocol in 1997; the integration of groups such as Amnesty International, WWF, Greenpeace or Transparency International; formal corporate initiatives such as AA1000, SA8000, the OECD Guidelines or the Global Agreement itself; In addition to the emergence of organizations such as the Global Reporting Initiative or the Ethos Institute, these events have served as a basis for building the concept of Corporate Social Responsibility (History of Social Responsibility, 2009).

\section{a) General Objective}

To assess the corporate social responsibility in a public hospital through the Boston College method.

b) Specific Objectives

- Determine the knowledge of the hospital staff about corporate social responsibility.

- Identify the actions performed by the institution regarding social responsibility.

- Demonstrate that employees are not aware of the activities that the hospital performs regarding social, environmental matters.

c) General Hypothesis

According to the Boston College method the public hospital, where the measurement instrument applied, is up the level of commitment in at least three of its dimensions.

\section{d) Specific Hypothesis}

HT The knowledge of the hospital staff regarding social responsibility is broad.

HE The actions performed by the hospital with regards to social responsibility are 5 .

$H^{\circ}$ The hospital does not perform social, environmental actions. 


\section{ThEORETICAL FRAMEWORK}

Trying to find a definition of social responsibility is hard, since every institution or author has one; However, to have a clear position, you can start with the proposal of the Mexican Center for Philanthropy (CEMEFI): Corporate Social Responsibility, is the conscious and consistent commitment to fulfill the mission and vision of the company. Companies must consider the economic, social and environmental expectations of all their stakeholders, showing respect for people, ethical values, the community and the environment, thus contributing to the construction of a common good.

The Secretary of Economy (2016) says: Corporate social responsibility (CSR) defined as the active and voluntary contribution to social, economic and environmental improvement by the companies, with the purpose of improving their competitive and evaluative situation, as well as their added value (Secretary of Economy, 2016).

Corporate Social Responsibility is to do business based on ethical principles in accordance with the law. The company (not the entrepreneur) has a role before society, before the environment in which it operates.

CSR is not philanthropy; the purpose is not that companies become charities since companies are made to be profitable. This implies that companies adopt an active and responsible posture based on the impact economic, social and environment of their operations. This culture is a way of doing business that guarantees greater sustainability and economic growth for the company over time. (World Bank Group U.S.A., 2006).

This way, it is understood that corporate responsibility is not something unrelated or added to the original function of the company. On the contrary, it implies complying with it being aware that it will have a positive or negative impact, in a director indirect manner, internally or externally, to groups and communities linked to its operation. It is the ability to respond to these challenges, seeking to maximize positive impacts and minimize negative ones, conducting better businesses when meeting these expectations (Cajiga C., N/D).

The commitment of the hospitals with CSR must start with an internal communication plan that makes all workers that depend on their area know the mission, vision, and values thereof. This should not be a simple internal note, but it must be performed with all the services and departments, reaching commitment in all of them. Also, hospitals cannot be limited to designing a strategy; they should also implement it, see how it works and of course, assess it to improve to face future actions. Hospitals and health centers are to evolve from a health care center into a sanitary professional-patient interaction center. In a world where good and bad quality information is at the reach of our fingertips, there are a lot of hospitals that should invest more in empowering patients through schools for patients and scientific dissemination actions in their community.

Definitely, there is a lot of work to do, both in the institution and with the staff and their main clients: the patients. (Diario Responsable, RSE Global, 2017).

\section{ili. Conceptual Framework}

Ethics: The term ethics comes from the Greek word ethos, which meant "dwelling," "place where one lives" and which ended up indicating the peculiar and acquired "character" or the "way of being" of someone; the habit (mos-more: the moral). Ethics has an intimate relationship with morals, so much that they are often confused. (http://conceptodefinicion.de, N/D)

Social Responsibility: Social responsibility is the commitment, obligation, and duty that individuals, members of a society or company have to contribute voluntarily for a more just company and to protect the environment. Social responsibility can comprise negative and positive; the former refers to abstaining from action; the latter to acting. (https://www. significados.com, N/D).

Commitment: It refers to a type of obligation or agreement of a human being towards others when facing an event or situation. Isan obligation that must be satisfied by the person that acquired it. Also, is the ability of a person to become aware of the importance of complying with something previously agreed. Being a person that complies with his/her commitments is considered a value and a virtue since this usually ensures success and fulfillment of future projects. (http://concepto.de.,N/D)

Philanthropy: The etymology of this word is Greek, under the name of " $\varphi \imath \lambda \alpha v \theta \rho \omega \pi \iota \alpha$ " (philanthropia), formed by

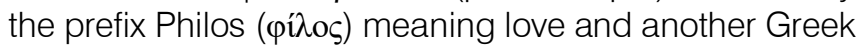
word Anthropos ( $\alpha \dot{v} \theta \omega \omega \pi \mathrm{s})$ referring to man, the human being. Philanthropy understood as an attitude of love attitude that individuals and institutions may have for humankind in general. (https://definicion.com.,N/D).

\section{Methodology Criteria}

\section{a) Nature}

Qualitative or non-traditional investigation according to Bonilla and Rodriguez (2000) quoted by Bernal (2010), is oriented towards examining specific cases and not to generalization. It is concerned not with general measuring, but with qualification and description of the social phenomenon from determinant features, as perceived by the elements within a given situation. (Bernal, 2010). This was applied research since it used the Boston College method measurement instrument, was non-experimental research since the study 
variables were not manipulated; the method was applied and worked on already existent situations or events, was descriptive research since only one variable was included and it was measured through indicators.

\section{b) Design}

This research had a non-experimental, transactional, and descriptive. Research assessment was developed only during a specific time. Therefore it is transactional; the proposal included one variable, it was descriptive.

\section{c) Method}

Bernal (2010) defines the inductive method as using the reasoning to obtain conclusions that come from particular facts accepts as valid with a general application. (Bernal, 2010)

d) Mode

Fieldwork and with bibliographic support.

e) Place and time

The investigation work was carried out in the city of Chihuahua, Chihuahua, from September to December 2017.

\section{f) The Population of Interest}

The directors and staff of a public hospital of the city of Chihuahua and, during a second part, four patients, two suppliers and five neighbors of the hospital were interviewed, and they participated voluntarily.

\section{g) Sample Framework}

The measurement instrument was applied taking into consideration the information provided by each department of the hospital.

h) Analysis Unit

Management Director, medium and low-level staff from a public hospital in the city of Chihuahua. In the second part, four patients, two suppliers and five neighbors of the hospital were interviewed.

\section{i) Kind of Sampling}

Not probabilistic due to convenience.

j) Size of the Sample

- Management Director

- Head Nurse

- Head of Emergency Department

- Head of Gynecology and Obstetrics

- Accountant

- General Cashier

- Head of Maintenance

- Director's Secretary

$2^{\text {nd }}$ Part

- Four patients

- Two suppliers

- Five neighbors
Patients Profile:

- More than three days in the hospital

- Several hospitalizations

- Surgical patients

Suppliers Profile:

- Three years providing services to the hospital

- Several material deliveries per week

- Invoicing for more than $\$ 100,000$.00 per month

Neighbors Profile:

- Living in the sector for more than five years

- Voluntary participation

The study variable that assessed was: The corporate social responsibility through the Boston College method.

The indicators that describe the variables were:

- Social responsibility concept

- Strategic attempt

- Leadership

- Structure

- Management of social affairs

- Relations with agents (stakeholders)

- Transparency

Data collection performed:

Through the instrument of the Boston College method to assess the level of corporate social responsibility. For the second part, six questions made for the structured interview.

Information codification:

It was performed using the division format of the Boston College method and the second part listing the answers obtained.

\section{Results}

The first part, the dimensions with support questions that used, as well as the answers and the conclusion relative to each dimension, are shown below.

\section{Dimension 1}

The concept of Corporate Social Responsibility. For you, what is the role of the hospital: to obtain profits or provide goods and services or provide jobs, or to promote regional development or to take care of the natural environment? All of the above, or only some in particular?

$R 1$ (Management Director) The role is to give medical attention, to provide medical services to all kinds of patients, from government workers to the open population, with the same attention, as well as research and teaching, since we find doctors in training who will subsequently offered a job.

R3 (Head Nurse) The role of the hospital before society, is to generate a medical and hospital service, for patients who enter the hospital to obtain a benefit for their health. Also, the natural environment protected by separating the different types of residues and waste, 
placing them in ecological containers which have a specific color, always in compliance with the official Mexican regulation, which refers to this separation.

R2 (Head of Emergency Department) This responsibility has a lot of importance due to the fact that we are people specialized in the health field, the lessons obtained from school provide us a guideline to accept and learn responsibility from the moment the ambulance arrives up to taking the patient where he/she must assisted. The hospital seeks to generate medical attention more than any other option.

R4 (Head of Gynecology and Obstetrics) In our area the most important thing is the health of the mother and child, the economic aspect is not fundamental since it is a public hospital. On the other hand, a hospital is a training center, a space for the recovery of the individual's and the community's health. We think that health is part of the human being; it is a vision of the human being as social-biological being, where the recovery of the physical, emotional and integral state of the patient intervenes and the hospital works all those factors to benefit people.

R5 (Accountant) Particularly generating improvements in the hospital to benefit the populations and not obtaining economic benefits, as well as managing the resources ethically.

R6 (General Cashier) Almost all of them, since the objective of this hospital is to take care of the citizen's health, providing quality service, taking care of the environment, not so much generating profit.

R7 (Head of Maintenance) I think that all of them. In my case, taking care of the toxic waste or having them handled with proper care since we must take care of the environment, and worrying about the wellbeing of others.

$R 8$ (Director's Secretary)l think that all of them, from the service to society in the aspect of health, since most of the times they don't pay all of the hospital services since they are unprivileged people. The creation of jobs, since doctors that come to do their internships, are being trained and prepared and they often offered with a job.

Conclusion: Due to the obtained answers, the development level of the Corporate Social Responsibility in dimension one, the concept of Social Responsibility, the hospital is at stage 3. INNOVATION. Since it has staff in training, committed with the society it serves, further education and infrastructure; there is a deep commitment to learning; regulations in the transparency indicator.

\section{Dimension 2}

Strategic attempt: What is the purpose of Social Responsibility in the Hospital? To what extent is the CSR present in the hospital plans, strategies, programs, goods and services, organizational culture? How does it serve as a guide for the hospital's actions? Is CSR followed as a moral commitment or as a result of a costbenefit analysis?

R1 (Management Director) The extent is the greatest, since the highest standards held at a professional, technical and operational level, this work is about improving the health service for the community, it is the common goal of everyone working in this hospital, to shorten the times for the patients families, to try and give the internal patients the best service and that they feel comfortable.

R2 (Head Nurse) Every level of the hospital is concerned with this, from the Director to the staff in charge of each area, there is social responsibility towards the community, and it is perceived in the treatment of patients, in the services provided, with the best health attention possible for people. Regarding the organizational culture, we are all a family, there is a concern for people, from the management of biohazardous products, their transportation outside of the hospital, its administrative, cleaning, environmental care in the surrounding areas of the hospital.

R3 (Head of Emergency Department) We are all committed to providing a service, many times this is impossible, especially on a Friday or Saturday night, since many times patients outnumber us, but we try always assist them, especially those requiring urgent service. We have excellent general practitioners, internists, cardiologists, gynecologists, pneumologists, oncologists, in both shifts. The hospital works as a team, looking to give the best of us as a hospital. On the other hand, the hospital is always training us, and we have state of the art equipment and regulations that must observed at all times.

R4 (Head of Gynecology and Obstetrics) A common denominator is the support to economically disadvantaged people, that program to avoid the payment due to some discount or debt forgiveness is one of the programs that work best in this hospital. I consider social responsibility to be present mostly because we assist vulnerable people.

R5 (Accountant) Several topics are addressed, according to the programs, planning, organization, following the hierarchical lines and most importantly, the moral commitment to all of society.

R6 (General Cashier) Social responsibility is a moral responsibility, and that is how Corporate Social Responsibility is in our hospital, and that is how it should be. It can also combine with the cost-benefit the people who work here require payment. Doctors and nurses and administration staff, we all are a team, and somehow, we have that social responsibility.

R7 (Head of Maintenance) As Head of maintenance, I must always check the doctors' equipment and the staff under my control checks the facilities, services, the most 
sophisticated equipment so that the hospital can provide a service. I believe that the responsibility we have with society is always present in our work.

R8 (Director's Secretary) Part of my daily work is to follow up the training of Doctors, Nurses and Administration Staff. Also, the communication of the director with each person of the different areas is constant. Each year, a work plan performed to assist the population with the best quality. I believe that this allows us to see that Social Responsibility is the commitment of the hospital and in no way the economic aspect of it.

Conclusion: The analysis of these answers indicates that the hospital is at STAGE 3: INNOVATION. There is constant communication from Management; there is constant training in such hospital, as well as surveillance, which makes diverse matters related to Social Responsibility broader.

\section{Dimension 3}

Leadership: What is the management level to CSR? Are directors aware of the idea of CSR? How much commitment do they demonstrate and to what extent do they go from words to action?

R1 (Management Director) This hospital's management is efficient, so is the commitment, there are weekly meetings held with the Heads of every service to see the improvements of this commitment to society, and why not say it, to see the errors that can be improved, all of this makes us better employees and persons. Responsibility is very high, due to the meetings of the Heads, in which the information of the agreements is passed on. We have a quality department that supervises: services, regarding the times, paperwork that is managed and is very important because then the times in any area, service, room and emergency room can be shortened, which is a priority.

R2 (Head Nurse), The director, cares for everything; he is someone that has demonstrated his/her leadership, who observes everything and realizes what is missing and what hasn't been done, of social responsibility, of what is right and what is wrong, management shows one hundred percent commitment.

R3 (Head of Emergency Department), The managers, are aware since in every room there are containers for sharp instruments, utensils, red bags, every area has what it's necessary. Contaminated objects and all waste are separated and the companies that dispose of the trash know of the guidelines and rules.

R4 (Head of Gynecology and Obstetrics) It is pursued as a moral commitment, most of the staff working here are very humane people; there is a commitment with patients that predominate more than others. On the other side, we have performance measurements that we should always take into consideration, as well as goals in each of the departments.
R5 (Accountant) There is excellent communication with management since we have training courses, according to the needs of every department. The way of implementing and acting done in the quality area, where it assessed whether the topics learned actually acted.

R6 (General Cashier) Of course, senior management is committed with people: they are the motor of this hospital. There is communication between the operational and managerial part.

$R 7$ (Head of Maintenance) The management is aware of the commitment and is checking that we are all working as we should because we should always fulfill the goals.

$R 8$ (Director's Secretary), The responsibility of managers is at one hundred percent since it helps their certifications, both inside and outside the hospital, to fulfill their goals. The plans within the Hospital go from management to the lowest position, implemented immediately, and an assessment done of the results obtained in each level.

Conclusion: Regarding the answers obtained, the Hospital is at stage 4. INTEGRATION, due to the coordination, collaboration, innovation and everything related to Social responsibility, it tries to manage it as part of each of the strategies implemented in the levels, performance goals and indicators established, results are evaluated for the measurement of quality and obtaining the certifications and they are in continuous training in environmental matters.

\section{Dimension 4}

Structure: How are the responsibilities and tasks of CSR distributed in the hospital's organization? Is there a person, group, area or department formally responsible for CSR?

R1 (Management Director) Yes, there is a department in charge, it is conducted individually through each Head, by department, and periodic meetings are held, where the department improvements and faults had by the department are evaluated along with the quality staff; they are the ones in charge of determining the social benefits that have achieved, also the safety and hygiene commission participates, they review potentially unsafe conditions within the hospital.

R2 (Head Nurse) There are people in charge in the nursing department, of general services as well; there's people who oversee social responsibility.

R3 (Head of Emergency Department) To be honest I don't have know of this as a formal area, but I think the quality department is in charge of this aspect.

R4 (Head of Gynecology and Obstetrics) Social work, emergencies and each area have their respective Heads, in charge of it.

R5 (Accountant) No, I do not know anything about it. 
R6 (General Cashier) I do not know if there is any department linked to CSR because this link was lost, there is no area responsible.

R7 (Head of Maintenance) Each level has a Head responsible for the area that is in charge of social responsibility, and that is defined by management by day, afternoon and night shifts.

$R 8$ (Director's Secretary) There are nursing and medical teaching areas, immediate supervisors are in charge of these; the quality department does its performance assessments according to programs. The quality department is the one in charge of evaluating the implementations of CSR programs.

Conclusion: As a consequence of the preceding opinions, the hospital is at stage 2. COMMITMENT, where senior management increases the expectations of society towards the hospital, starts monitoring what happens outside in matters of Social Responsibility and adopts the visions about their roles and responsibilities. Meanwhile, the policies regarding jobs, health, safety, and environmental practices are adapted. In this regard, the Heads of each level are in charge of the evaluation, monitoring, and results that they wish to obtain.

\section{Dimension 5}

Management of social affairs: How does the hospital addresses social-environmental matters? How proactive is the company in social-environmental? To what extent they are included in their policies, plans and programs and considered part of their performance?

R1 (Management Director) Yes, the hospital is governed by the Mexican Official Regulation of Environmental Safety, the hospital holds very high standards in that regard, as well as the separation of sharp materials, the ones impregnated with blood, common trash, all of that has a delimited area, an equipped person in charge, who is also in charge of the collection and final disposal of such biohazardous waste, the colored diamond is used, with following and coordination with the maintenance area to know the degree of priority and preference. A person through a car performs the periodic collection two to three times each shift; there is a space in the patio, which is constituted before the law as storage, while a specialized external supplier, evaluates its final disposal.

R2 (Head Nurse) Everything is under control since we have restaurant areas around here. Therefore there must be a responsibility about to toxic waste and also because there are organizations that are always supervising.

R3 (Head of Emergency Department) We have very strong regulations regarding our responsibility, both for society, meaning the zone where we are, as well as the environment, not contaminating with our waste.
R4 (Head of Gynecology and Obstetrics) One hundred percent, social-environmental matters are managed in this hospital, aside from the environmental, which done through the separation of trash, biological waste, cleaning of bedding. There are training for these topics of waste and trash separation. There are also notices posted for employees, patients, etc.

R5 (Accountant) I don't know any environmental improvement plan, only the standardization of biohazardous waste management, which were included in the policies and programs, which are part of the hospital quality evaluations.

R6 (General Cashier) There are waste and trash management and other courses to which we attend.

$R 7$ (Head of Maintenance) Continually, checking that the procedures of the medical service were carried out, as well as the cleaning ones, since there is a constant assessment, because if something goes wrong, it affects both the staff and patients, meaning everyone is affected.

$R 8$ (Director's Secretary) So far, there is a project that is being worked on, especially in the environmental matters to recreate internal patios for patients to go out and be more connected with the outside, with the environment, in the social aspects due to the attention given, a maternity corridor was also planned.

Conclusion: In regard to the answers received, the hospital is at stage 2: COMMITMENT strongly committed with health, safety and environmental practices under the ecologic procedures of the Official Mexican Regulation of Environmental Safety.

\section{Dimension 6}

Relationship with stakeholders: Which is the level of commitment with stakeholders? How many stakeholders (clients, suppliers, workers, government, nongovernmental bodies, etc.) does the company communicate with? How broad is the communication of the hospital with the stakeholders? How committed is the company with stakeholders?

R1 (Management Director) There is a high and effective communication from the hospital's managers towards the employees, information about social development programs, of improvements for external population, for the staff. The commitment from the government is very high. The agencies we communicate with are: companies, patients, suppliers, workers, federal, state and municipal government; all of this is done to have a very high number of users to offered service. The hospital is in excellent condition, with equipment and the processes that are already established are carried out, as in the nursing department, their direct bosses are in continuous communication, the quality department continuously checks and verifies, there is a very high commitment, since, at the end of the day, the patient and their families are the ones who benefit the most. 
R2 (Head Nurse) There are several governmental organizations, volunteers, students, that are involved here in the hospital and with whom the hospital has excellent communication, we have always supported each other in whatever is needed.

R3 (Head of Emergency Department), The relationship of commitment, is towards the patient. However, there are other groups such as students who come to trained and the open population who are our clients, and I consider there is a good relationship with them.

R4 (Head of Gynecology and Obstetrics) The relationship is excellent, it managed by levels, patients given preference, but it depends on the patient's conditions. Communication is adequate, all the information necessary provided, and if they want to further their education, even more, it is authorized. The commitment level is very intense; any fault solved immediately.

R5 (Accountant) The hospital has relations with stakeholders and medication suppliers. The hospital attention quality is humane, and communication is broad. There is a harmonious environment with the workers; practically everyone has a congruent relationship with the different levels and the different areas.

R6 (General Cashier) The hospital receives lots of support, not only from the government sector but also from other people that are interested in participating in the development of this hospital, such as volunteers and interns. There is a commitment to stakeholders, and most of the employees are committed.

$R 7$ (Head of Maintenance) There is communication, through a suggestion box from both parties, which provides the necessary feedback to make corrections. The extent of this communication is good, essential. The hospital is $100 \%$ committed with the stakeholders, especially the patients, to provide a better service.

R8 (Director's Secretary) The guidelines establish how the treatment with different suppliers is going to be carried out according to the official regulation, supervising, taking courses with suppliers, etc. Everything that provided is regulated, and we have special care since it can affect or benefit both the hospital and the clients. The hospital is morally committed to its stakeholders.

Conclusion: In this regard, the hospital is at stage 4: INTEGRATION since the hospital has a relation with various stakeholders to provide and control the output of different materials, equipment, and waste.

\section{Dimension 7}

Transparency: How open is the hospital regarding its financial, social and environmental performance? Does the hospital have policies and practices in terms of transparency? In what topics and since when does the company maintain transparency practices? How open is the hospital in regards to transparency?

R1 (Management Director) The openness in terms of transparency is total since we have a webpage where the general population informed of all the financial statements and movements. On the other hand, there are economic and political transparency programs because, we notify through informative sheets and memos posted in core points of the building, such as the time clock, the information comes from the senior management, where we can check any inner and outer inquiry. This practice has been accentuated and maintained during the last ten years.

R2 (Head Nurse) To be honest I do not know. I know there is a webpage where they inform of the financial situation of the hospital, but I haven't kept up with that; we worry more about the health of the patient in here.

R3 (Head of Emergency Department) It is my understanding that there is a webpage since a long time ago, and the environmental programs are known through this means, but I haven't seen anything.

R4 (Head of Gynecology and Obstetrics) I do not know how we are, but I believe there is a medium degree of transparency with everything in general.

R5 (Accountant) With the audits, we achieve that transparency, and it covers all topics, including financial, human resources, material, equipment, services, visit times, economic, moral and social topics. The degree of openness that the hospital maintains regarding transparency is one hundred percent; all departments are open and available for auditors to do their job.

R6 (General Cashier) We permanently have auditors that check the efficient economic operation, on the other hand, we have a webpage, and if there is a person who is not satisfied with what posted there, we can respond to him personally.

R7 (Head of Maintenance) Regarding transparency I do not know, I imagine there must be, I haven't checked, but the managers that govern this organization are very accessible, kind and honest people, so I believe that showing the matter of transparency would not be any problem. I consider the hospital to be open.

R8 (Director's Secretary) The government itself establishes the policies, since we are an extension, audits are being permanently performed for several years, and we are accountable to the government.

Conclusion: According to the answers given by the respondents, the hospital is at stage 4, INTEGRATION, as is observed in table 1 , due to the fact that it is periodically monitored in quality aspects that result in the certifications necessary for exemplary operation and appreciation of society for the health service provided and thus, being able to give it in an excellent way. 
Table 1: The grid with the obtained results

\begin{tabular}{|c|c|c|c|c|c|}
\hline & $\begin{array}{c}\text { Stage 1 } \\
\text { Elemental }\end{array}$ & $\begin{array}{c}\text { Stage } 2 \\
\text { Commitment }\end{array}$ & $\begin{array}{c}\text { Stage } 3 \\
\text { Innovation }\end{array}$ & $\begin{array}{c}\text { Stage } 4 \\
\text { Integration }\end{array}$ & $\begin{array}{c}\text { Stage } 5 \\
\text { Transformation }\end{array}$ \\
\hline $\begin{array}{l}\text { Social } \\
\text { Responsibility } \\
\text { Concept }\end{array}$ & $\begin{array}{l}\text { The health and } \\
\text { hospital } \\
\text { service. } \\
\text { Complying with } \\
\text { regulations and } \\
\text { standards. }\end{array}$ & $\begin{array}{l}\text { Policies and } \\
\text { programs. } \\
\text { Bilateral } \\
\text { communication } \\
\text { and training. } \\
\text { Environment. }\end{array}$ & $\begin{array}{l}\text { High technology, } \\
\text { Commitment, } \\
\text { Innovation and } \\
\text { knowledge. }\end{array}$ & $\begin{array}{l}\text { Collaboration, } \\
\text { strategies, } \\
\text { follows up, } \\
\text { internal and } \\
\text { external } \\
\text { reports. }\end{array}$ & $\begin{array}{l}\text { Coordination, } \\
\text { values, benefit to } \\
\text { open population. }\end{array}$ \\
\hline $\begin{array}{l}\text { Strategic } \\
\text { Attempt }\end{array}$ & $\begin{array}{l}\text { Social } \\
\text { responsibility, } \\
\text { plans, } \\
\text { programs, } \\
\text { policies and } \\
\text { values. }\end{array}$ & $\begin{array}{l}\text { Vulnerable } \\
\text { community. } \\
\text { New visions, } \\
\text { evaluation. }\end{array}$ & $\begin{array}{l}\text { Vigilant role, } \\
\text { growing } \\
\text { communication } \\
\text { and training. }\end{array}$ & $\begin{array}{l}\text { Internal } \\
\text { reports, } \\
\text { analysis, } \\
\text { prevention. }\end{array}$ & $\begin{array}{l}\text { Radical changes, } \\
\text { transformation, } \\
\text { active, internal } \\
\text { and passive } \\
\text { participation. }\end{array}$ \\
\hline Leadership & $\begin{array}{l}\text { High } \\
\text { commitment, } \\
\text { normative } \\
\text { responsibility. }\end{array}$ & $\begin{array}{l}\text { Monitoring, } \\
\text { active leader, } \\
\text { constant } \\
\text { communication } \\
\text { and } \\
\text { surveillance. }\end{array}$ & $\begin{array}{l}\text { Update with } \\
\text { agents, staff and } \\
\text { infrastructure. }\end{array}$ & $\begin{array}{l}\text { Team work, } \\
\text { coordination, } \\
\text { periodical } \\
\text { reports. }\end{array}$ & $\begin{array}{l}\text { Practice of values. } \\
\text { External } \\
\text { evaluations. }\end{array}$ \\
\hline Structure & $\begin{array}{l}\text { Work, health, } \\
\text { safety and } \\
\text { environmental } \\
\text { practices. }\end{array}$ & $\begin{array}{l}\text { Renovation of } \\
\text { infrastructure, } \\
\text { coordination of } \\
\text { responsibilities. }\end{array}$ & $\begin{array}{l}\text { General training } \\
\text { and growing } \\
\text { communication. }\end{array}$ & $\begin{array}{l}\text { Indicators, } \\
\text { reports, } \\
\text { monitoring and } \\
\text { new strategies. }\end{array}$ & $\begin{array}{l}\text { Ambition to stand } \\
\text { out in health } \\
\text { services. }\end{array}$ \\
\hline $\begin{array}{l}\text { Management of } \\
\text { Social Matters }\end{array}$ & $\begin{array}{l}\text { Standard } \\
\text { compliance, } \\
\text { high- } \\
\text { awareness in } \\
\text { SR. }\end{array}$ & $\begin{array}{l}\text { Commitment, } \\
\text { evaluation, } \\
\text { constant } \\
\text { information. }\end{array}$ & $\begin{array}{l}\text { Deepening the } \\
\text { commitment, } \\
\text { learning and } \\
\text { innovation. }\end{array}$ & Proactive. & $\begin{array}{l}\text { Defined } \\
\text { integration. }\end{array}$ \\
\hline $\begin{array}{l}\text { Relationship } \\
\text { with } \\
\text { Stakeholders }\end{array}$ & $\begin{array}{l}\text { Unilateral, } \\
\text { assumes } \\
\text { responsibility. }\end{array}$ & $\begin{array}{l}\text { Bilateral, safety } \\
\text { and hygiene } \\
\text { programs. }\end{array}$ & $\begin{array}{l}\text { Growing } \\
\text { commitment. }\end{array}$ & $\begin{array}{l}\text { Responsible } \\
\text { alliance. }\end{array}$ & $\begin{array}{l}\text { Mutual } \\
\text { participation. }\end{array}$ \\
\hline Transparency & $\begin{array}{l}\text { High-openness } \\
\text { position. }\end{array}$ & $\begin{array}{l}\text { High } \\
\text { expectations. }\end{array}$ & $\begin{array}{l}\text { External } \\
\text { regulations. }\end{array}$ & $\begin{array}{l}\text { Statistical } \\
\text { reports. }\end{array}$ & $\begin{array}{l}\text { Constant } \\
\text { dissemination. }\end{array}$ \\
\hline
\end{tabular}

\section{Second Part}

In addition to asking the employees of the hospital, the researchers asked patients, suppliers, and neighbors, their perception about how the hospital acts as a socially responsible entity, then their main points of view are shown.

\section{Patients}

1. How is the treatment you have received in the hospital?

P1: Well, what I do not like is that the visits are very short and only one person can enter at a time, and all my family stays outside.

P2: The same as in all hospitals, they are all sad and one wouldn't want to be here.

P3: Good, I have been here several times, so I think one gets used to it.

P4: Good, I believe no one likes hospitals.

2. You have been in this hospital several times, has there been a change in the treatment you received here?

P1: I have been here several times, the first one I thought the nurses were very strict, but then I realized that we are a lot of patients and they don't have a lot of time for each of us.

P2: Yes, there have been several changes, at the beginning they didn't rapidly identify us, but now they come in with some papers, and there is more control of everything, even visits.

P3: Yes, there have been good changes, now everything is cleaner, and patients are better treated.

P4: This is the sixth time I've been here; I'm always getting sick. Everything has changed, the beds are different, the doctors now come to see us, and that's very good, I just hope this is the last time I'm here.

3. Have the operation, curation and appointments date been met?

P1: Now they do, but before, they gave us a date, and when the day came, they changed it again. My operation date was changed three times the first time I was here. Now they give out an appointment, and they respect it.

P2: That has actually changed a lot, before, one honestly never knew when the operation or the 
appointment would be, and now they don't change them.

P3: They have changed my operation date thrice, this last time I had the operation, though.

P4: Yes, that is the most common thing, having your operation date changed, especially the appointments. But I believe that is already changing.

4. Have your relatives been receiving the information they requested, about your situation as a patient?

P1: No, neither them nor me, when I ask them they tell me to wait for the doctor to arrive and when he does, he doesn't say anything.

P2: No, my family never knows who to ask.

P3: It is very hard to get information because we are a lot of patients.

P4: I don't know why but it is very problematic for them to get information.

5. Do you think that the service, in general, is good? P1: Yes

$P 2$ : It is a hospital for us, it is okay.

$P 3:$ Well, in general terms, yes.

P4: Yes

6. If you could recommend something to the hospital, what would it be?

P1: To stop leaving our families with no information of when our operation was, how it went, in what room we are, all of that, it is very necessary them and for me

P2: I believe that everything should be free because we have no money and what they charge is a lot for us.

P3: I don't know what I could recommend, but maybe that all our family could visit us at whatever time they can come.

P4: To help us, until we heal.

\section{Suppliers}

1. How is the treatment that you have received from the hospital staff?

P1: Good, no problem I have been delivering material for this hospital for more than eight years and everything are fine in general terms.

P2: They have changed their staff, and when they are getting to know us, treatment is not very good. It later is, without issues.

2. In this last year, has there been any change in the treatment that you have received in the hospital?

P1: It has changed, in the previous management, we had problems for the payment of invoices, but now it has changed. On the other hand, with the social responsibility program, I believe they are paying attention to everything, even us suppliers.
P2: They have had a lot of changes, from the treatment to patients to cleanliness, schedules, everything has changed.

3. Have they respected your dates for invoice revision, invoice payment, and inventory revision?

P1: Yes, this has been very good for us, because now we can schedule when they will do their order due to the constant revision that they are doing to the inventories, on the other hand, they now respect the invoice revision and the payment schedule.

P2: Well, respecting dates has been relatively recent because before, one had to come up to 5 times and often, they were changed against receipt because they had no resources.

4. If you could make any recommendation to the hospital, what would you recommend?

P1: Well, I believe that training all the staff, especially those that are in customer's care, because I have witnessed how rude they are to people.

P2: Keeping on paying all outstanding debts from the previous administration.

Neighbors:

1. What benefits have you had to live near to a hospital?

N1: I have never thought about that, but I believe that the fact of feeling that if in case of a health problem, you are one step away from the hospital.

N2: When we moved, the hospital was already there, and we thought that, precisely because of that, it would be a very safe sector, due to all the movement during the day and night.

N3: Knowing that you have doctors nearby and that in case of an emergency, well, you count on that.

N4: When we bought the house we didn't think of which could the benefits be, we liked it, and it had an affordable price for us.

N5: I don't know. I don't know which could be the benefits of living near a public hospital.

2. How has your relationship with the hospital managers been?

N1: Very difficult, because we go and complain because they don't listen to the problems we have with them and they don't receive us.

N2: We don't look for them a lot because they don't mind about the problems brought by that the fact that they do not control people that are outside of the hospital day and night and who invade our sidewalks and garages.

N3: We are tired of having the hospital as a neighbor. Unfortunately, we have not been able to move to another house. 
N4: What can I tell you? If we had known about the problems of living near to a hospital, we wouldn't have bought that house.

N5: There is no relationship with them.

3. Which are the main problems that you have faced due to the fact of being a neighbor of the hospital?

N1: I believe there are several, but the main one is the trash which accumulates because of all the street vendors around the hospital and who never clean, leaving the front of the house dirty.

N2: The main ones are having our garages invaded, that there are people day and night and we don't feel safe because of that much people.

N3: There are a lot, but mainly the trash which accumulates because the hospital throws it away every eight days, attracting a lot of animals, not only street dogs and cats but worse: rats!

N4: The street vendors and the trash left by all the people buying their products. I believe they should removed from outside of the hospital.

N5: We are already tired of having someone blocking our garage every time we want to go out, no matter how many signals we place, how many big rocks we put outside, they don't move and on the side, all the trash gathering everywhere.

4. What recommendations would you make to the hospital?

N1: Simple, having cleaning staff that is sweeping the surrounding streets day and night, only for them to realize the amount of trash we have to throw away every day.

N2: That they would lease a wide area to use as a parking lot so that people don't have to invade our garages. I believe that it wouldn't be so costly and it would be beneficial for everyone.

N3: Simple, for them to clean and be held accountable for all the trash that they have around the hospital.

N4: To take the street vendors away, imagine all the diseases that the people are buying their products get.

N5: We have spoken to the neighbors about garages, and we believe that the best thing would be for them to hire parking lots for the patient families.

\section{Conclusions}

According to the answers obtained, it concluded that the managerial and operational staff of the hospital is committed to their patients, suppliers, and the environment. They are aware of the commitment of individual and collective Social Responsibility, according to the regulations that govern the hospital.

The structure and management of social matters are in the Commitment stage
In this regard, the Director is a proactive, committed and responsible leader in the compliance of regulations and standards, safety and service which implements strategies, coordinates responsibilities properly to increase awareness in their staff and follow up the measurements and obtained results. The commitment in all was verified through the answers, as well as the constant information in all hierarchical levels.

The concept of social responsibility and strategic intent are in stage 3 of Innovation.

The hospital has permanently been acquiring state of the art equipment, it is committed because it seeks to increase awareness of the staff on the care and management of toxic and harmful materials for the environment, its control and surveillance, as well as the communication with them, they are open to learning and to uphold the law in order to comply with certifications.

The leadership, transparency, and relationship with the stakeholders are in the Integration stage

According to the analyzed results, the hospital is in a stage of teamwork where they include strategies, goals, analyses, and indicators, training from the operational levels, which are in direct contact with the patient, everything in order to integrate the service, the improvement, the innovation and the practice of standards and policies established by external agents. Similarly, statistics reports are being submitted, monthly, others semiannually and those that have to be yearly, although there is no dissemination of financial activities.

About the objectives. Assessing the corporate social responsibility in a public hospital through the Boston College method. It was achieved by applying the Boston College measurement instrument, which allowed seeing that the highest stage the hospital found in is stage 4 of integration of the dimensions of leadership, relationship with stakeholders and transparency. In regards to the first specific objective: determining the knowledge of hospital staff about social responsibility. The fact that they are in the dimension of innovation in the aspect of social responsibility allows us to see that there is knowledge, but it is not enough. About the specific objective, identifying the actions that the institution conducts in matter of social responsibility, according to the responses of the interviewees, the following are being made: training, professional training, and efforts are being made to have transparency, such as the webpage.

Showing that the employees ignore the activities that the hospital conducts in social-environmental matters, this was also very evident with the responses of some of the interviewees.

Regarding the general hypothesis: according to the Boston College method, the public hospital where the measurement instrument was applied, which is in a commitment level of at least three dimensions, is rejected because there were only two indicators found at 
the commitment level, the structure and social affairs management.

About the specific hypothesis that the knowledge of the hospital staff about social responsibility is broad, is rejected according to the results because it is evident that exist a lack of information among the personnel. The second hypothesis that there are five fundamental actions that the hospital conducts in a matter of social responsibility is rejected since it found that there are only: the proper management of toxic waste, the application of the standard, monitoring of guidelines. The last hypothesis that the hospital does not conduct social-environmental actions is rejected because there was no evidence found.

Out of the results of the interview conducted in the second part of the research, the most significant was the lack of attention towards the patient's family. About the hospital's neighbors, they are extremely upset with the hospital because they accumulate a lot of trash and they aren't careful with it and on the other hand because of all the street vendors around the hospital.

\section{Vil. Recommendations}

Since the higher stage in which the hospital is at is stage four of integration and only in three dimensions: leadership, relationships with stakeholders and transparency, the following recommendations were made:

- Dissemination of social responsibility and each of its dimensions to get all the staff involved.

- Developing programs, strategies and organizational culture, activities that foster and engage different stakeholders,

- Having spaces where the families of patients can rest and with this achieving a cleaner hospital.

- Providing information about the patient to families.

On the other hand, in relation to the second part of this research, several recommendations were made:

- Mainly, handling trash with more protection, since most of the times it is toxic and they have no care with its management.

- Similarly, removing the street vendors that also generate a lot of trash and a lot of insecurity for neighbors around the hospital,

- To consider the possibility of a public parking lot to avoid the invasion of the parking spaces of the homes around the hospital.

- About suppliers, they recommend training the staff in patient care, for them to provide an efficient service.

On the other hand, it is fundamental training the staff on toxic waste management and train them on social responsibility, it is not a simple concept, nor easy to understand, it implies the care of the environment, the care of the stakeholders, respect for the private property of the neighbors, sustainability, and the adequate treatment of the patient so that all the staff knows fully the commitment that they have as a health institution.

\section{BIBLIOGRAPHY}

1. Cajiga C., J. (N/D). Centro Mexicano para la Filantropia. México: CEMEFI.

2. Ley Estatal de Salud. (2012 йил 14-04). http://ordenjuridico.gob.mx/Documentos/Estatal/Chi huahua/wo22620.pdf. Retrieved 2017 йил 13-11 from

http://ordenjuridico.gob.mx/Documentos/Estatal/Chi huahua/wo22620.pdf:

http://ordenjuridico.gob.mx/Documentos/Estatal/Chi huahua/wo22620.pdf

3. Comision de las Comunidades Europeas. (2001 йил 18-7). Libro Verde: Fomentar un marco europeo para la responsabilidad social de las empresas. Retrieved 2017 йил 16-9 from http://www.oiss.org/ atprlja/?Libro-verde-sobre-Responsabilidad:

http://www.oiss.org/atprlja/?Libro-verde-sobreResponsabilidad

4. Bernal, C. (2010). Metodología de la Investigación. Bogotá: Pearson.

5. Diario Responsable, la RSE Global. (2017 йил 1810).

https://diarioresponsable.com. Retrieved 2017 йил 29-10 from

https://diarioresponsable.com.:

https://diarioresponsable.com/opinion/24052-rsc-

en-hospitales

6. Historia de la Responsabilidad Social. (2009 йил 112).

https://www.expoknews.com. Retrieved 2017 йил 39 from

https://www.expoknews.com/historia-de-la-

responsabilidad-social/:

https://www.expoknews.com/historia-de-la-

responsabilidad-social/

7. http://concepto.de. (N/D). http://concepto.de/ compromiso/\#ixzz5D5X72cRo.

Retrieved 2017 йил 13-11 from http://concepto.de/compromiso/ \#ixzz5D5X72cRo: http://concepto.de/compromiso/\#ixzz5D5X72cRo

8. http://conceptodefinicion.de. (N/D). http://concept odefinicion.de/etica/. Retrieved 2017 йил 1-11 from http://conceptodefinicion.de/etica/: http://conceptodefinicion.de/etica/

9. https://definiciona.com. (N/D). https://definiciona.com/filantropia/. Retrieved 2017 йил 03-11 from https://definiciona.com/filantropia/: https://definiciona.com/filantropia/

10. https://www.significados.com. (N/D). https://www.significados.com/responsabilidadsocial/. Retrieved 2017 йил 03-11 from 
https://www.significados.com/responsabilidadsocial/:

https://www.significados.com/responsabilidadsocial/

11. Sangronis, J., Gonzalez G., O., \& Otto, J. (2014). La responsabilidad social desde la perspectiva de las PYMES del sector constructor. Revista arbitrada del Centro de Investigación y Estudios Gerenciales. Barqusimeto Venezuela , 16-28.

12. Secretaría de Economía. (2016 йил 27-05). https://www.gob.mx. Retrieved 2017 йил 03-10 from https://www.gob.mx/se/articulos/responsabilidadsocial-empresarial-32705:

https://www.gob.mx/se/articulos/responsabilidadsocial-empresarial-32705

13. World Bank Group U.S.A. (2006). https://site resources.worldbank.org. Retrieved 2017 йил 12-10 from https://siteresources.worldbank.org.: https://siteresources.worldbank.org/CGCSRLP/Res ources/Que_es_RSE.pdf 